\title{
Caracterización petrofísica y alterabilidad de las piedras de la Catedral de Sevilla
}

\section{Petrophysical caracterization and weatherability of the stones of the Seville Cathedral}

R. M. ESBERT; J. ORDAZ; F. J. ALONSO; V. G. RUIZ DE ARGANDOÑA; M. MONTOTO; R. MARCOS Y L. VALDEON

Fecha de recepción: $7-\mathrm{VI}-88$ Departamento de Geología, Universidad de Oviedo

\section{RESUMEN}

Se estudian las características petrográficas de los principales tipos de materiales calcáreos utilizados en la construcción de la Catedral de Sevilla, así como algunas de sus propiedades físicas y deformacionales más significativas. Se realizan, asimismo, ensayos de envejecimiento artificial acelerado, con objeto de evaluar la alterabilidad de las piedras, tanto del monumento como de sus correspondientes de cantera.

\section{SUMMARY}

The petrographical characteristics of the principal types of calcareous materials used in the construction of the Seville Cathedral, as well as some significant physical and deformational properties are presented. Artificial ageing tests were also carried out for evaluating the weatherability of those stones, both from the monument and from the corresponding quarries.

\section{INTRODUCCION}

Este estudio sobre las piedras de la Catedral de Sevilla tiene como finalidad aportar una serie de datos sobre la naturaleza y características de sus piedras de construcción, necesarios a la hora de plantear y elegir los métodos y productos de conservación más adecuados para las piedras de este monumento.

En este sentido se estudian, además de las características petrográficas de las distintas variedades rocosas, una serie de propiedades físicas estrechamente relacionadas con el movimiento del agua a través de las piedras $y$, en consecuencia, con los principales fenómenos de alteración. Por otro lado, el conocimiento de las características deformacionales proporciona, a su vez, valiosa información sobre el comportamiento geomecánico de dichos materiales rocosos. Su determinación se ha llevado a cabo aplicando, entre otras, técnicas no destructivas (ultrasónicas y de emisión acústica). Por último, se han realizado ensayos de envejecimiento artificial acelerado, a fin de conocer la durabilidad de los materiales pétreos, tanto del monumento como de cantera.

\section{INTRODUCTION}

The objective of this study about the stones of the Seville Cathedral is to provide a series of data on their nature and characteristics, required for planning and selecting the most appropiate methods and products of conservation for these stones.

In this sense, a series of physical properties closely related to the movement of water through the stones - and consequently, to the principal alteration phenomena-, as well as the petrographical characteristics of the different rock varieties, are studied. On the other hand, the knowledge of the deformational characteristics also provide a valuable information about the geomechanical behaviour of the materials, their determination being carried out by means of, among others, non destructive techniques (ultrasonic and acoustic emission). Finally, artificial ageing tests were performed with the aim of assessing the durability of the stones, both of monument and quarries. 


\section{LOS MATERIALES EN LA FABRICA}

La fábrica gótica de la Catedral de Sevilla está construída con materiales rocosos sedimentarios, de naturaleza calcárea. El tipo más abundante es una caliza fosilífera (biocalcarenita), de color amarillento en fractura fresca, y grisáceo en superficie expuesta a la intemperie (acentuado éste por las pátinas de suciedad). La textura es granuda, de grano generalmente grueso, resaltando la presencia de abundantes restos fósiles. Dentro de este tipo rocoso pueden distinguirse dos variedades petrográficas: a) una variedad de grano grueso a muy grueso, en la que son mayoritarios los restos de algas; b) otra de grano fino a medio, que presenta mayor proporción de bioclastos y granos de cuarzo.

Esta piedra ha sido la tradicionalmente empleada en la construcción de la fábrica catedralicia desde sus inicios, así como a lo largo de las siguientes etapas de construcción (siglos XVI a XVIII). Las canteras de procedencia, históricamente documentadas, son varias (Falcón, 1985), pudiéndose citar las de Jerez de la Frontera y Puerto de Santa Maria (Cerro de San Cristobal), Gandul, Utrera, Espera, etc. Debido a su naturaleza petrográfica y al tiempo que ha permanecido expuesta a los agentes ambientales, muestra rasgos de deterioro generalizado y, en consecuencia, es la que presenta mayores problemas de conservación. El repertorio de formas de alteración que exhibe este tipo de material pétreo es muy variado, alcanzando en algunos casos avanzados niveles de degradación (Figs. 1 y 2).

Los otros tipos rocosos presentes en la Catedral son minoritarios en cuanto al volumen que ocupan en la fábrica, y generalmente han sido utilizados en etapas más recientes de construcción y en reconstrucciones (S. XIX y XX).

Uno de ellos es una caliza oolítica de color blanquecino, resaltando en muestra de mano la presencia de oolitos de tamaño de grano variable, de fino a medio. Posiblemente parte de este material proceda de Gilena, aunque no se descartan otras procedencias (Martín et al. 1987). Este tipo rocoso muestra diversas texturas, no sólo en las distintas partes del rilonumento donde se halla ubicado, sino incluso dentro de un mismo sillar; estas diferencias son debidas principalmente a variaciones en el porcentaje y tamaño de los oolitos. Su coloración externa, contrasta abiertamente con el resto de materiales y, aparentemente, es el material más sano y mejor conservado. En relación con este hecho debe tenerse en cuenta que su colocación en

\section{THE FABRIC MATERIALS}

The Gothic fabric of the Seville Cathedral is built with sedimentary rock materials of calcareous nature. The most abundant type is a fossiliferous limestone (biocalcarenite), of yellowish colour in fresh fracture and greyish in surface exposed to the open air (this coloration being emphasized by soot patinas). The texture is grainy, of a grain size generally coarse, standing out the presence of abundant fossils. Two petrograhic varieties can be distinguished: a) a coarse or very coarse grain size variety, in which the remains of algae are majority; and b) another of fine to medium grain size, that presents a higher proportion of bioclasts and quartz grains.

This stone has been traditionally used in the construction of the Cathedral from the beginning, as well as along the following phases of construction (XVIth to XVIIIth centuries). There are several historically documented provenience quarries (Falcón, 1985), e.g. Jerez de la Frontera, Puerto de Santa María (Cerro de San Cristóbal), Gandul, Utrera, Espera, etc. Due to their petrographical nature and to the time of exposition to the environmental agents, these stones show signs of a general deterioration and, consequently, are the most problematic in order to their conservation. The forms of alteration that this limestone exhibits is very diverse, in some cases attainning advanced degrees of degradation (Figs. 1 and 2).

The other rock types present in the Cathedral are a minority with respect to the volume that they occupy in the fabric, and generally they have been employed in more recent phases of construction and in reconstructions (XIXth and $X X$ th centuries).

One of these stones is a oolithic limestone, whitish, standing out in hand sample the presence of oolithic of variable grain size, from fine to medium. Possibly part of this material proceeds from Gilena, although other sites are not discarded (Martín et al., 1987). This stone shows several textures, not only in different parts of the monument where it is located, but inclusive within a same ashlar; these differences being principally due to variations in the percentage and grain size of the ooliths. Their colour contrasts openly with the rest of the materials and, apparently, it is the most sound and best conserved material. In relation to this fact, it must be taken into account that its placement in the building is relatively recent (XIXth century); being situated mainly in the 
el edificio es relativamente reciente (siglo XIX); situándose principalmente en las puertas de las de las fachadas norte y sur - basamentos exteriores-, coronaciones de pináculos y torrecillas de restauración (Figs. 1 y 2).

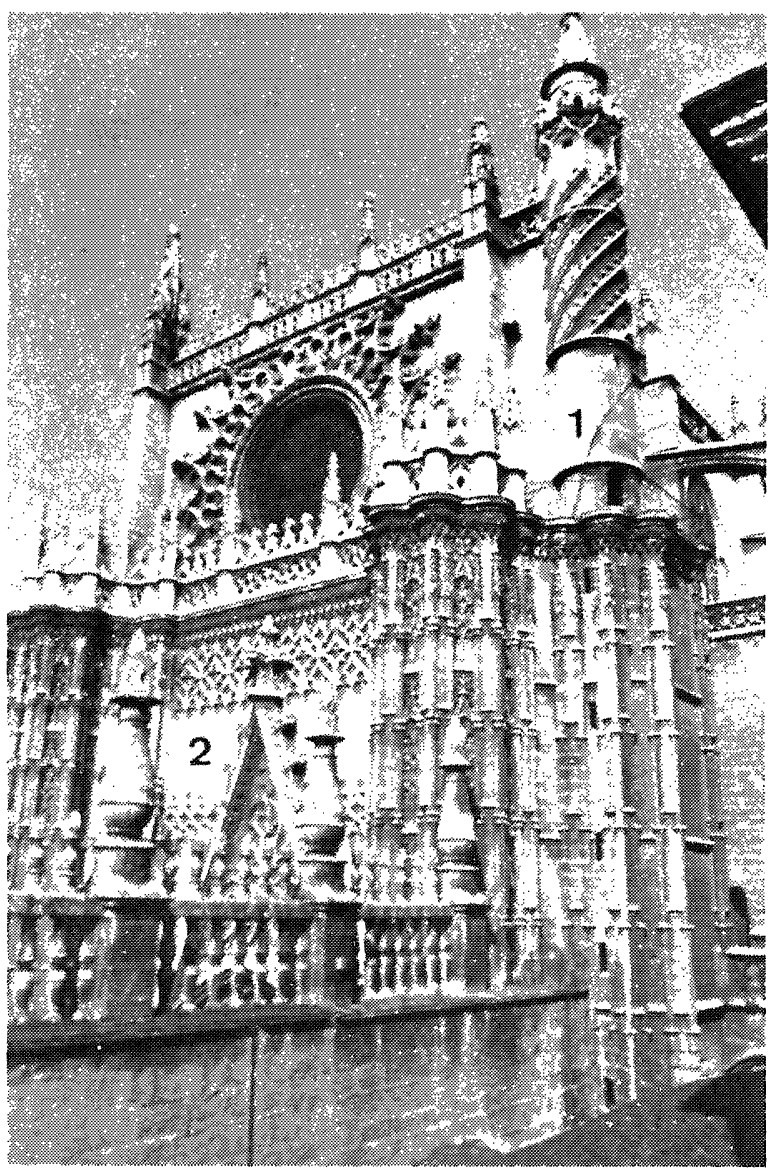

Fig. 1

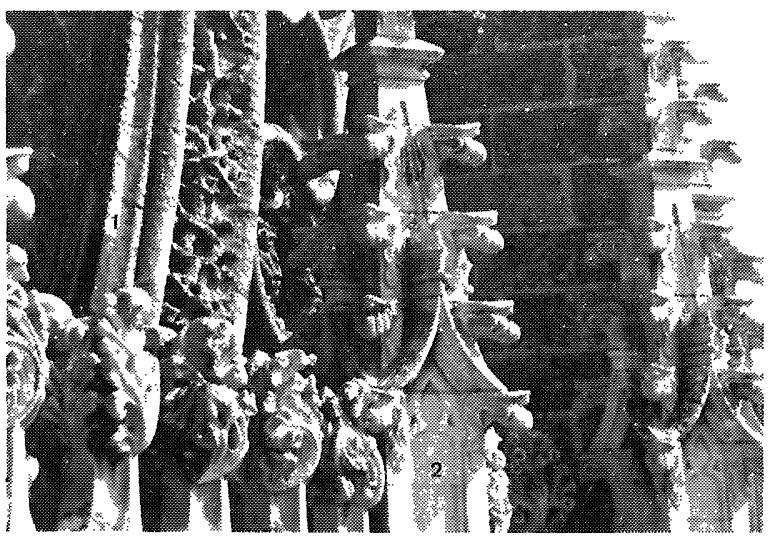

Fig. 2

Figs. 1 y 2.-Vista de la puerta de la fachada Sur de la Catedral de Sevilla en la que se distinguen fácilmente dos tipos de piedras: la fosilífera (1) y la oolítica (2). En la Fig. 2 puede verse un detalle de las anteriores litologias.

Figs. 1 and 2.-A view of the South facade of the Seville Cathedral. Two types of stone can be distinguished: Fossiliferous (1) and oolithic (2). Fig. 2: Detail of the mentioned lithologies.

MATERIALES DE CONSTRUCCION, Vol. 38, n.॰210, abril/mayo/junio 1988 doors of the North and South façades, and in the crown of pinnacles and little towers of restoration (Figs. 1 and 2).

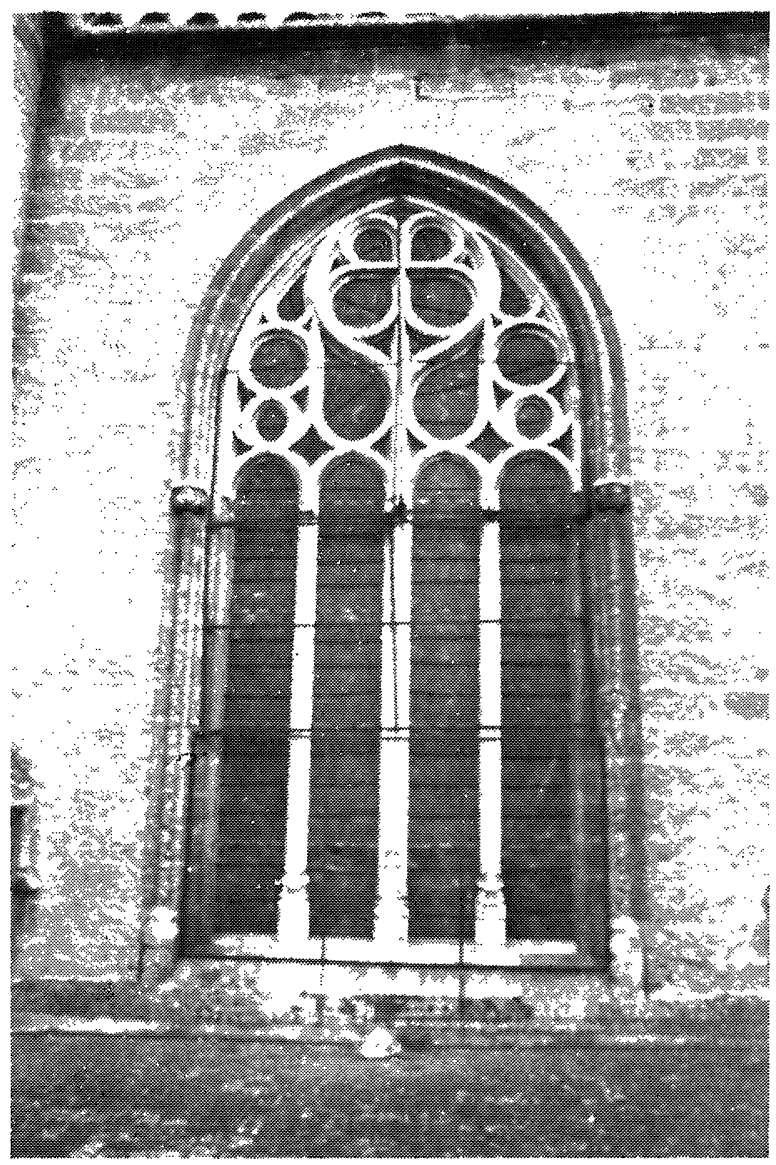

Fig. 3.- Tracerias en un ventanal realizadas con caliza micrítica. Nótese el contraste con respecto a la piedra fosilifera del muro.

Fig. 3.-Filigranes of a large window made of the micritic limestone. Note the contrast with respect to the fossiliferous one of the wall. 
El otro material pétreo destacable es una caliza micrítica que presenta en superficie tonalidades pardo-blanquecinas. Su aspecto es muy homogéneo, mostrando microfósiles en muy baja proporción. Este tipo de material se ha utilizado de forma restringida, especialmente en la restauración de parte de los ventanales (columnas y filagranas) que soportan las vidrieras (Fig. 3). Su procedencia no nos es conocida. Su estado de conservación es bueno a primera vista, aunque en algunos casos se observan desprendimientos de partículas al tacto con los dedos, lo que indica su proclividad a la desagregación granular.

En la Tabla I se muestran los mencionados tipos de materiales, junto a su localización en el monumento, lugar de procedencia y edad geológica.
The other stone is a micritic limestone, presenting superficially brown-whitish colorations, and showing a very homogeneous aspect, and microfossils in a very low proportion. This type of material has been used in a restricted form, especially in the restoration of parts of the large windows (columns and filigranes) that support the glass windows (Fig. 3). Their provenience is not known to us. Their state of conservation is good at first sight, though in some cases particle detachments by finger touch are obseved, so indicating their proclivity to the granular disaggregation.

Table I shows the above mentioned types of materials, as well as their location in the monument, site of provenience and geological age.

TABLA I

Materiales rocosos utilizados en la Catedral de Sevilla

\begin{tabular}{|l|l|l|l|}
\hline \multicolumn{1}{|c|}{$\begin{array}{c}\text { Tipo de } \\
\text { piedra }\end{array}$} & \multicolumn{1}{c|}{$\begin{array}{c}\text { Localización } \\
\text { en monumento }\end{array}$} & $\begin{array}{c}\text { Procedencia } \\
\text { (canteras) }\end{array}$ & $\begin{array}{c}\text { Edad } \\
\text { geológica }\end{array}$ \\
\hline Caliza Fosilífera & $\begin{array}{l}\text { Portadas del Bautismo y del } \\
\text { Nacimiento; Capilla Real; y la } \\
\text { mayor parte del Templo. }\end{array}$ & $\begin{array}{l}\text { Gandul, Espera, Puerto de } \\
\text { Sta. Maria, Utrera, Jerez. }\end{array}$ & Mioceno Superior. \\
\hline Caliza Micrítica. & $\begin{array}{l}\text { Restauraciones (ventanales y } \\
\text { sus tracerias). }\end{array}$ & - & Jurásico (Dogger-Malm). \\
\hline Caliza Oolítica. & $\begin{array}{l}\text { Puertas de las fachadas } \mathrm{N} \text { y } \\
\text { S; basamentos exteriores, re- } \\
\text { mate de pináculos y torreci- } \\
\text { llas restauradas, etc. }\end{array}$ & Posiblemente Gilena. & \\
\hline
\end{tabular}

TABLE

Rock materials used in the fabric of Seville Cathedral

\begin{tabular}{|l|l|l|l|}
\hline \multicolumn{1}{|c|}{$\begin{array}{c}\text { Type } \\
\text { of stone }\end{array}$} & $\begin{array}{c}\text { Location in the } \\
\text { monument }\end{array}$ & $\begin{array}{c}\text { Provenience } \\
\text { (quarries) }\end{array}$ & $\begin{array}{c}\text { Geological } \\
\text { age }\end{array}$ \\
\hline Fossiliferous limestone & $\begin{array}{l}\text { "Bautismo" and “Nacimiento" } \\
\text { façades; Royal Chapel; and } \\
\text { most part of the temple. }\end{array}$ & $\begin{array}{l}\text { Gandul, Espera Pto. de } \\
\text { Sta. María, Utrera, Jerez. }\end{array}$ & - \\
\hline Micritic limestone & Restorations. & Dogger-Malm (Jurassic). \\
\hline Oolithic limestone. & $\begin{array}{l}\text { Nand S façades, pinaccles, li- } \\
\text { ttle towers restored. }\end{array}$ & Possibly Gilena. \\
\hline
\end{tabular}

\section{CARACTERISTICAS PETROGRAFICAS}

\subsection{Caliza fosilífera}

Es una calcarenita, formada por agregados de algas rojas, otros granos carbonatados (restos

\section{PETROGRAPHICAL CHARACTERISTICS}

\subsection{Fossiliferous limestone}

It is a calcarenite, formed by red algae aggregates, other carbonated grains (fossil

MATERIALES DE CONSTRUCCION, Vol. 38, n.॰ 210, abril/mayo/junio 1988 
fósiles) y, en menor proporción, granos de cuarzo (Tabla II). Pueden distinguirse dos variedades extremas: una de grano grueso, con componentes algales de hasta $0,5 \mathrm{~cm}, y$ otra de grano más fino (250 a $300 \mu \mathrm{m})$, más rica en cuarzo. Dicho cuarzo es mayoritariamente microcristalino, oscilando su tamaño entre 200 y $500 \mu \mathrm{m}$. Los agregados algales pueden llegar a representar un $75 \%$ en volumen, adaptándose - por sus formas irregulares- a los espacios intersticiales. Entre los restos fósiles se observan foraminíferos, crinoideos, moluscos, briozoos, corales, etc. Presentan óxidos de hierro que comunican a la roca una tonalidad ocre-amarillenta y, en muy baja proporción, arcillas, feldespatos y chert. remains) and, in a lesser proportion, quartz grains (Table II). Two extreme varieties can be distinguished: one of coarse grain size, with algal components up to $0,5 \mathrm{~cm}$; and other of finer grain size (250 to $300 \mu \mathrm{m})$, richer in quartz. This quartz is mainly microcrystalline, their grain size varying from 200 to $500 \mu \mathrm{m}$. The algal aggregates can attain up to $75 \%$ in volume, their irregular forms adapting to the interstitial spaces. Among the fossil remains were observed foraminifera, crinoidea, moluscs, bryozoa, corals, etc. The rock present iron oxides that favour an ochre-yellowish coloration and, in very low proportion, clays, feldspars and chert.

TABLA II

Composición mineralógica

\begin{tabular}{|l|c|c|c|}
\hline Tipo de piedra & Calcita & Cuarzo & Filosilicatos \\
\hline Catedral & & & indic. \\
Fosilífera & $45-97$ & $3-55$ & - \\
Micrítica & 95 & 5 & indic. \\
Oolítica & 100 & - & \\
\hline
\end{tabular}

TABLE II

Mineralogical composition

\begin{tabular}{|l|c|c|c|}
\hline Type of stone & Calcite & Quartz & Phyllosilicates \\
\hline Cathedral & & $3-55$ & traces \\
Fossiliferous & $45-97$ & 5 & - \\
Micritic & 95 & - & traces \\
Oolithic & 100 & \\
\hline
\end{tabular}

La textura es mayoritariamente tipo "grainstone" (Dunham, 1962), estando constituida por restos de algas y bioclastos. Prensenta algo de cemento microesparítico en posiciones intra e intergranulares (Figs. 4 y 5). Los espacios vacios son de tamaño muy variable, y pueden atribuirse a porosidad primaria intergranular $y$, en menor proporción, a porosidad secundaria de tipo móldico. Se observan también poros intergranulares en restos de corales. El análisis de la porosidad se incluye en el apartado 4.1.
The texture is mainly of grainstone type (Dunham, 1962), being formed by algae remains and bioclasts, presenting some of microesparitic cement in intra and intergranular positions (figs. 4 and 5). The voids are very variable in size, and can be attributed to intergranular primary porosity and, in a lesser proportion, to secondary porosity of moldic type. Intergranular pores in the coral remains are also observed. The analysis of the pore system is included in section 4.1. 


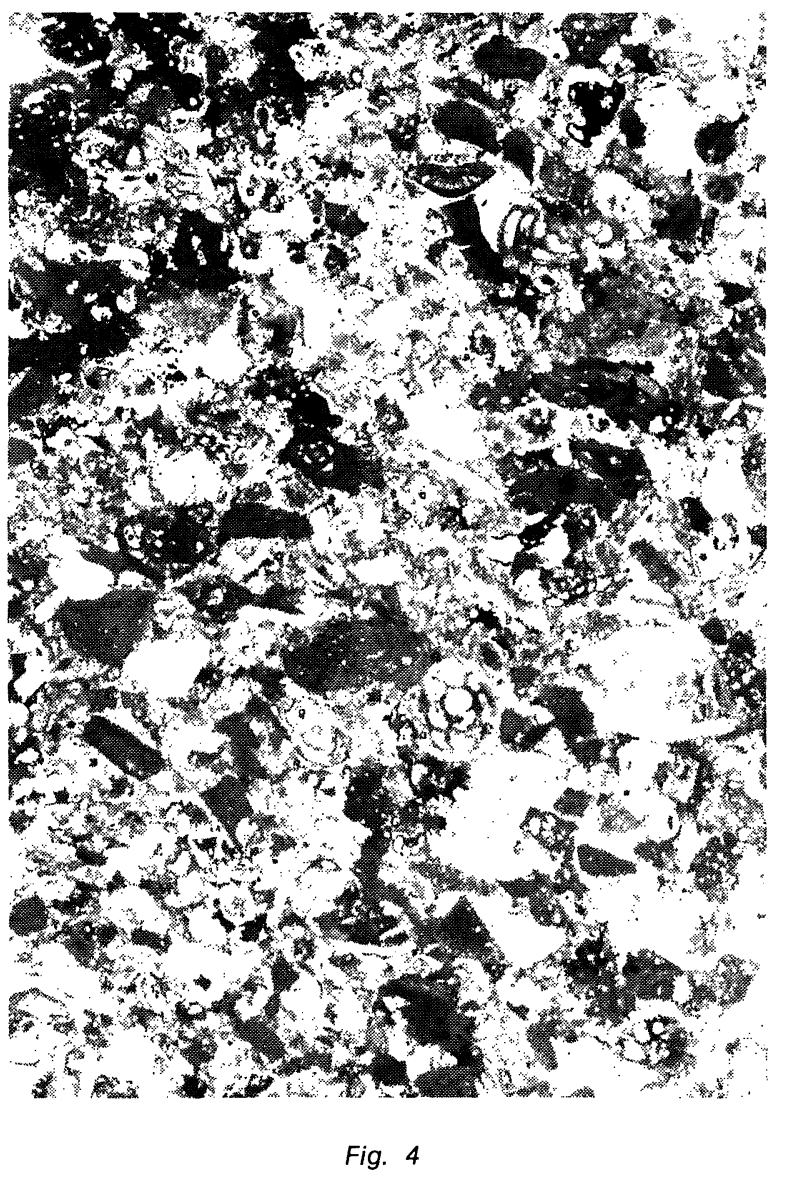

Figs. 4 y 5.-Dos aspectos de la caliza fosilífera de la Catedral de Sevilla. Izquierda: variedad con menos cuarzo. Derecha: variedad cuarcifera. (N.P. $\times 16)$.

\subsection{Caliza micrítica}

Se trata de una caliza de aspecto muy homogéneo, presentando algunos restos fósiles - principalmente valvas de ostrácodos - diseminados al azar, así como granos de cuarzo tamaño limo (30 a $60 \mu \mathrm{m})$ y algunos núcleos de esparita. En menor proporción, contiene óxidos de hierro y arcillas (Fig. 6). La textura es lodosa, tipo "mudstone" (Dunham, 1962), muy homogénea. Los poros son generalmente menores de $15 \mu \mathrm{m}$ de diámetro (microporos).

\subsection{Caliza oolítica}

Es una caliza de aspecto granudo, en la que pueden observarse tres tamaños medios de grano: uno alrededor de $1 \mathrm{~cm}$ (rodolitos); otro alrededor de $0,5 \mathrm{~mm}$ (peloides y algunos oolitos); y otro de unas 100 micras (pellets). Los granos están formados por micrita (Fig. 7).

Entre los componentes aloquímicos, apenas se observan restos fósiles, si bien presenta algún intraclasto. La roca se halla

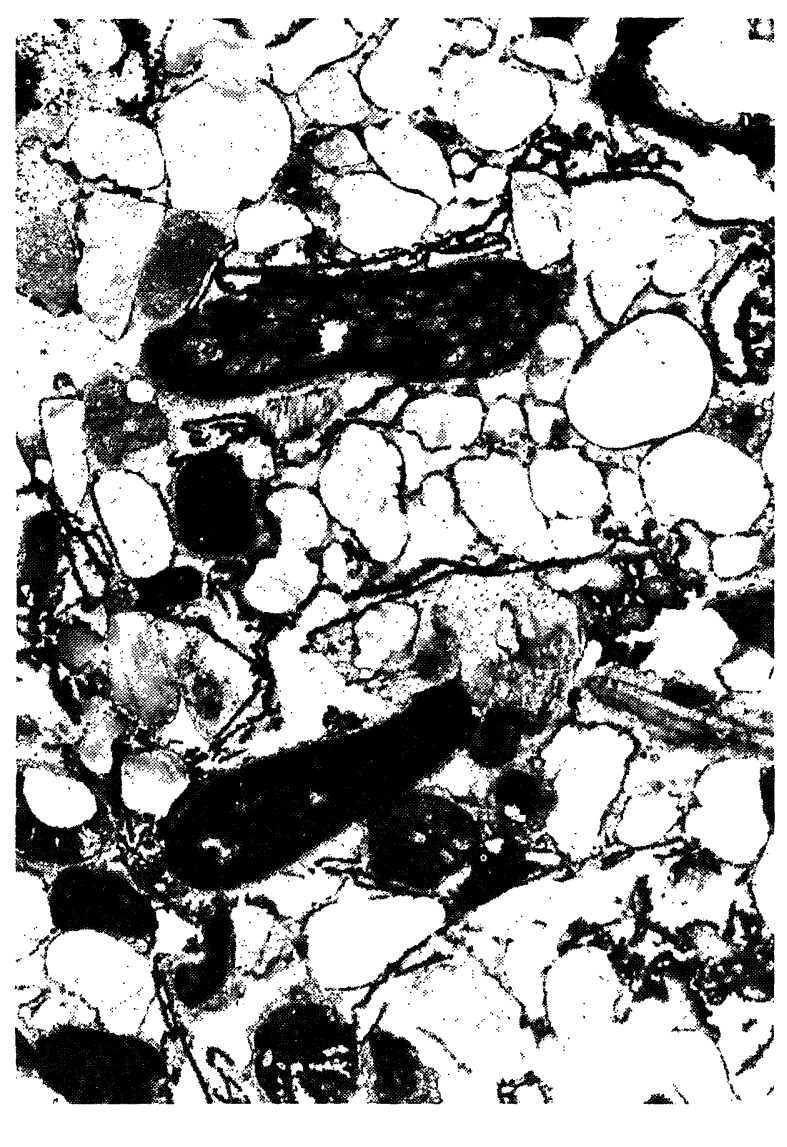

Fig. 5

Figs. 4. and 5.-Two aspects of the fossiliferous limestone of the Seville Cathedral. Left: Variety with less quartz content. Right: Quartzose variety. (P.N. X 16).

\subsection{Micritic limestone}

It is a limestone of a very homogeneous aspect, presenting some fossil remains - principally ostracods valves - aleatory disseminated, as well as quartz grains of lime grain size (30 to $60 \mu \mathrm{m})$ and some esparitic nucleii. In a lesser proportion it contains iron oxides and clays (Fig. 6). The texture is of mudstone type (Dunham, 1962), very homogeneous. The pores are generally lesser than $15 \mu \mathrm{m}$ diameter (micropores).

\subsection{Oolithic limestone}

It is a limestone of a grainy aspect, in which three mean grain sizes can be observed: one around $1 \mathrm{~cm}$ (rodolites); other around $0,5 \mathrm{~mm}$ (pelloids and some ooliths); and other of about $100 \mu \mathrm{m}$ (pellets). The grains are formed by micrite (Fig. 7).

Among the allochemical components, fossil remains are scarcely observed, althoungh some intraclast is present. The rock is 


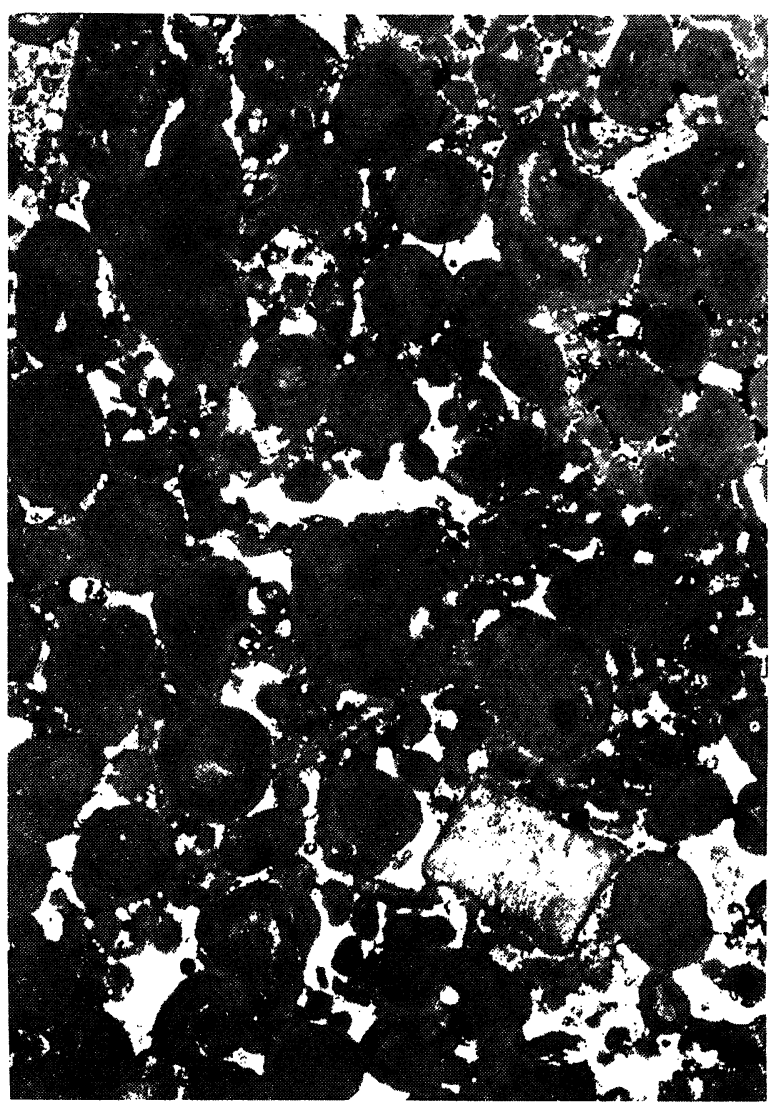

Fig. 6

Fig. 6 y 7.--Izquierda: aspecto al microscopio de la caliza micrítica de la Catedral de Sevilla. Se aprecia el carácter homogéneo de grano fino. Derecha: aspecto de la textura de la piedra oolítica. Puede observarse su heterometría granular (N.P. $\times 16)$.

heterogéneamente cementada, pudiéndose distinguir dos clases de cemento: uno de tamaño micrita a microesparita, situado alrededor de algunos granos; y otro de tamaño esparita, ocasionalmente de tendencia poiquilítica. La textura es de tipo "grainstone" (Dunham, 1962), débilmente cementada. Los poros son intergranulares, abundantes y de tamaño variable.

\section{PROPIEDADES FISICAS $Y$ DEFORMACIONALES}

\subsection{Propiedades Físicas}

Las propiedades físicas determinadas, siguiendo recomendaciones de la I.S.R.M y C.N.R.-I.C.R., han sido algunas de las más directamente relacionadas con la captación y circulación del agua por el interior de las piedras. En la Tabla III se recogen los valores medios de las mismas, tanto para las piedras del monumento como para las de cantera.

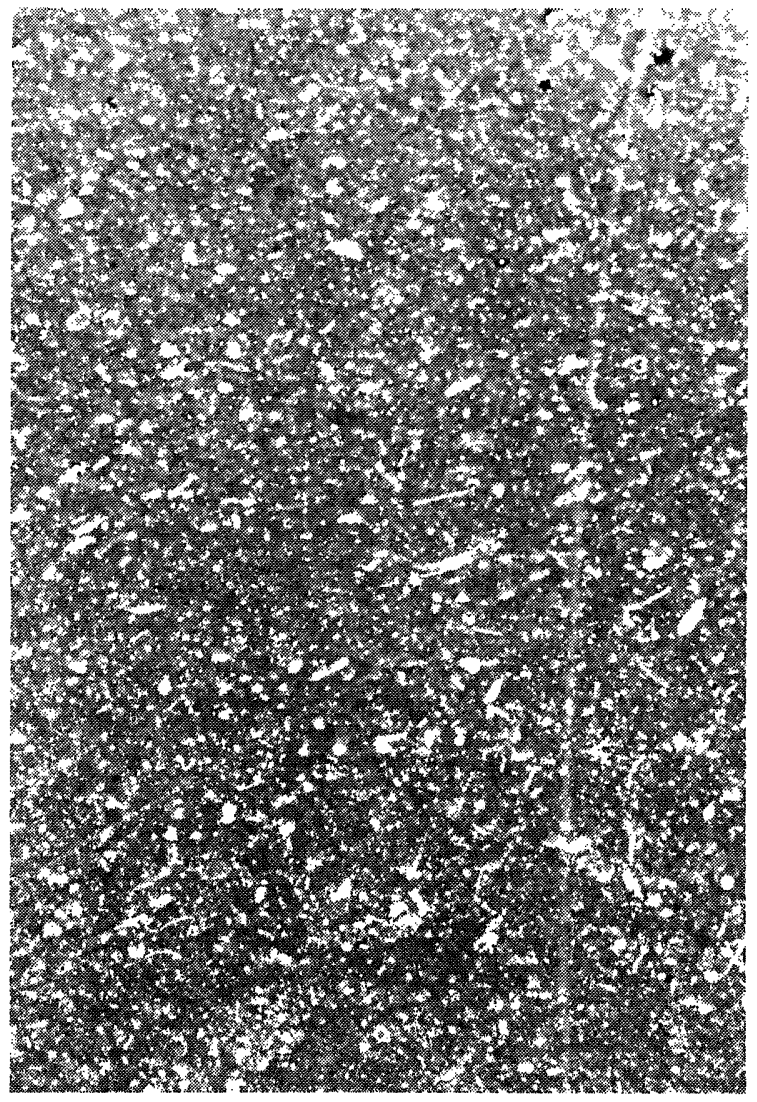

Fig. 7

Figs. 6 and 7.-Left: An aspect of the micritic limestone under microscope. The homogeneous character is well shown. Right: An aspect of the texture of the oolithic limestone. The granular heterometry can be observed. (P.N. X 16).

unhomogenously cemented, and two cement classes can be distinguished: one of micritic to microesparitic size, located around some grains; and other of esparitic size, occasionally of poikilitic tendency. The texture is of grainstone type (Dunham, 1962), weakly cemented. The pores are intergranular, abundant and of variable size.

\section{PHISICAL AND DEFORMATIONAL PROPERTIES}

\subsection{Physical properties}

The physical properties. were determined according to the I.S.R.M. and C.N.R. -I.C.R suggested methods, and some of the most directly properties related to the sorption and movements of water through the stones were selected. Table III shows the mean values of those properties, both of monument and quarry stones. 
TABLA III

Propiedades físicas

\begin{tabular}{|c|c|c|c|c|c|}
\hline $\begin{array}{l}\text { Tipo } \\
\text { de piedra }\end{array}$ & $\underset{\mathrm{g} / \mathrm{cm}^{3}}{\rho_{\mathrm{d}}}$ & $\begin{array}{l}\mathrm{n}_{0} \\
\%\end{array}$ & $\begin{array}{l}W_{s} \\
\%\end{array}$ & $\begin{array}{l}\mathbf{S}_{\mathbf{r}} \\
\%_{\%}\end{array}$ & $\underset{\mathrm{kg} / \mathrm{m}^{2} \cdot \mathrm{h}^{1 / 2}}{\mathbf{C}}$ \\
\hline \multicolumn{6}{|l|}{ Catedral: } \\
\hline Fosilifera & $1,72-1,92$ & $24-30$ & $12-18$ & $73-82$ & $51-227$ \\
\hline Micrítica & 2,03 & 18 & 9 & 94 & - \\
\hline Oolítica & 2,11 & 17 & 7 & 71 & 9 \\
\hline \multicolumn{6}{|l|}{ Cantera: } \\
\hline Fosilífera & $2,04-2,28$ & $14-23$ & $6-12$ & $67-77$ & $6-337$ \\
\hline Oolítica & $2,31-2,48$ & $8-14$ & $3-6$ & $97-98$ & $13-30$ \\
\hline
\end{tabular}

$\rho_{\mathrm{d}}=$ Densidad de la roca seca

$\mathrm{n}_{0}=$ Porosidad abierta.

$\mathrm{W}_{\mathrm{s}}=$ Contenido en humedad de saturación.

$\mathrm{S}_{\mathrm{r}}=$ Grado de saturación.

C $=$ Coeficiente de capilaridad.

TABLE III

Physical properties

\begin{tabular}{|c|c|c|c|c|c|}
\hline $\begin{array}{c}\text { Tipe } \\
\text { of stone }\end{array}$ & $\underset{\mathrm{g} / \mathrm{cm}^{3}}{\rho^{3}}$ & $\begin{array}{l}\mathrm{n}_{0} \\
\%\end{array}$ & $\begin{array}{l}\mathbf{W}_{\mathbf{s}} \\
\%\end{array}$ & $\begin{array}{l}\mathbf{S}_{r} \\
\%\end{array}$ & $\underset{\mathrm{kg} / \mathrm{m}^{2} \cdot \mathrm{h}^{1 / 2}}{\mathrm{C}}$ \\
\hline \multicolumn{6}{|l|}{ Cathedral: } \\
\hline Fossiliferous & $1,72-1,92$ & $24-30$ & $12-18$ & $73-82$ & $51-227$ \\
\hline Micritic & 2,03 & 18 & 9 & 94 & - \\
\hline Oolithic & 2,11 & 17 & 7 & 71 & 9 \\
\hline \multicolumn{6}{|l|}{ Quarry: } \\
\hline Fossiliferous & $2,04-2,28$ & $14-23$ & $6-12$ & $67-77$ & $6-337$ \\
\hline Oolithic & $2,31-2,48$ & $8-14$ & $3-6$ & $97-98$ & $13-30$ \\
\hline
\end{tabular}

\footnotetext{
$\rho_{\mathrm{d}}=$ Density.

$\mathrm{n}_{\mathrm{O}}=$ Open porosity.

$\mathrm{W}_{\mathrm{s}}=$ Saturation moisture content

$\mathrm{S}_{\mathrm{r}}=$ Degree of saturation.

$\vec{C}=$ Coefficient of capillarity.
}

De los datos expuestos se deduce que los distintos tipos rocosos estudiados presentan una notable variabilidad en sus propiedades físicas. Ademas, dentro de una misma variedad rocosa, y de una muestra a otra, hay también notables variaciones en los valores de las propiedades físicas medidas, especialmente en la caliza fosilifera y en la piedra oolítica de cantera.

Los bajos valores de densidad aparente de la roca seca, para este tipo de materiales, concuerdan con los altos porcentajes de espacios vacios existentes en estas rocas.

La porosidad comunicada en todas las muestras ensayadas presenta valores altos,
From these data it can be deduced that the different studied rock types present a remarkable variability in their physical properties. Likewise, within a same stone type, there are also significant variations in the measured properties, especially in the fossiliferous limestone and in the oolithic stone from the quarry.

The low values of apparent density of dry rock for these types of materials agree with the high percentages of voids existing in those stones.

In all the stones tested, the open porosity presents high values, although within the usual 
aunque dentro de los límites usuales para este tipo de materiales carbonatados.

En las Figs. 8 y 9 se muestran las curvas de absorción libre de agua con respecto al tiempo, para las diferentes variedades ensayadas (Alonso et al., 1987a).

\section{SEVILLA MONUMENTO}

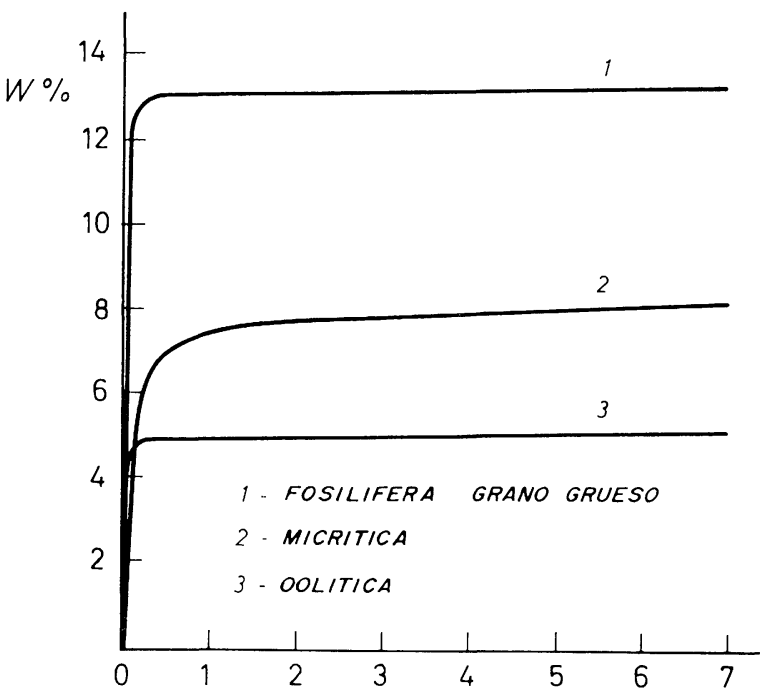

Fig. 8.-Curvas de absorción libre de agua con respecto al tiempo, para las variedades pétreas de la Catedral de Sevilla. (1) Fosilífera; (2) Micrítica; (3) Oolítica.

Fig. 8.-Water free absorption curves with respect to time, for the stone varieties of the Seville Cathedral. 1) Fossiliferous; 2) Micritic; 3) Oolithic.

De acuerdo con el trazado de las curvas se puede deducir que las piedras que más agua absorben son las del monumento. Todas las variedades ensayadas muestran un comportamiento similar en la primera hora del ensayo, salvo la fosilífera de Gandul. Ello conlleva la absorción de prácticamente toda el agua en los primeros minutos (primer tramo de la curva), tendiendo luego a estabilizarse (tramo horizontal de la curva).

Por lo que respecta a los valores del coeficiente de capilaridad (C), puede decirse que éstos abarcan una gama muy amplia, Figs. 10 y 11 . Por ejemplo, para la caliza fosilífera puede variar entre valores tan dispares como 51 y 227 , en el caso de las muestras de monumento; y entre 6 y 237 , en el caso de las de cantera. Esto supone coeficientes de capilaridad que fluctúan entre valores considerados bajos y muy altos.

Mediante porosimetría de inyección de mercurio se ha efectuado el análisis del limits for these types of carbonate stones.

In Figs. 8 and 9 are shown the water free absorption curves with respect to time, for the different tested varieties (Alonso et al., 1987a).

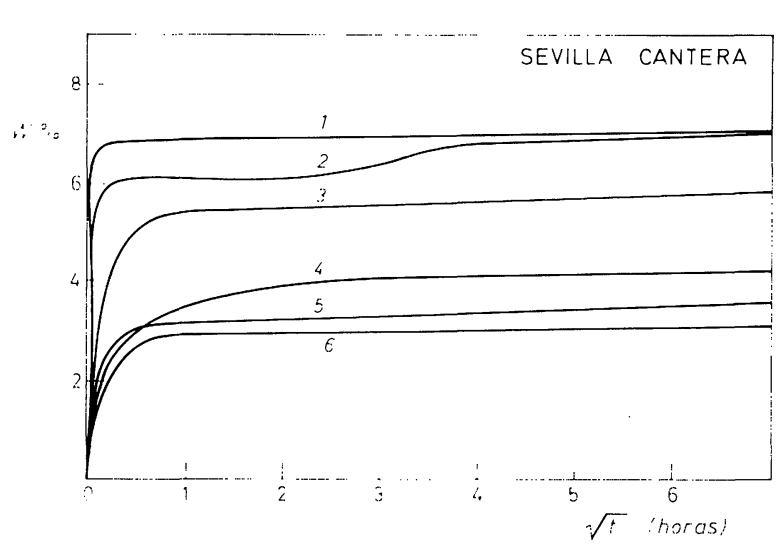

Fig. 9.-Curvas de absorción libre de a zua en relación al tiempo. 1, 2 y 4: Piedra fosilífera (Mairena del Alcor, Pto. de Santa María y Gandul, respectivamente); 3, 5 y 6: Piedra oolítica (Gilena)

Fig. 9.-Water free absorption curves with respect to time. 1, 2 and 3: Fossiliferous stone (Mairena del Alcor, Pto. de Sta. Maria and Gandul, respectively); 3, 5 and 6: Oolithic stone (Gilena).

According to these curves it can be deduced that the most water absorbent stones are those of the monument. All the tested varieties, except the fossiliferous from Gandul, shows a similar behaviour during the first hour of the test; this behaviour comporting the absorption of practically all the water in the first minutes (first step of the curve), and subsequently a tendence to equilibrium (horizontal step of the curve).

As for the coefficient of capillarity $(C)$ is concerned, it can be said that the values obtained are very extensive, Figs. 10 and 11. For instance, values from 51 to 227 were measured for the fossiliferous limestone of the monument; and from 6 and 237 in the case of the quarry samples. This represents coefficients of capillarity fluctuating between values considered low and very high.

The analysis of pore structure has been realized by means of mercury injection 


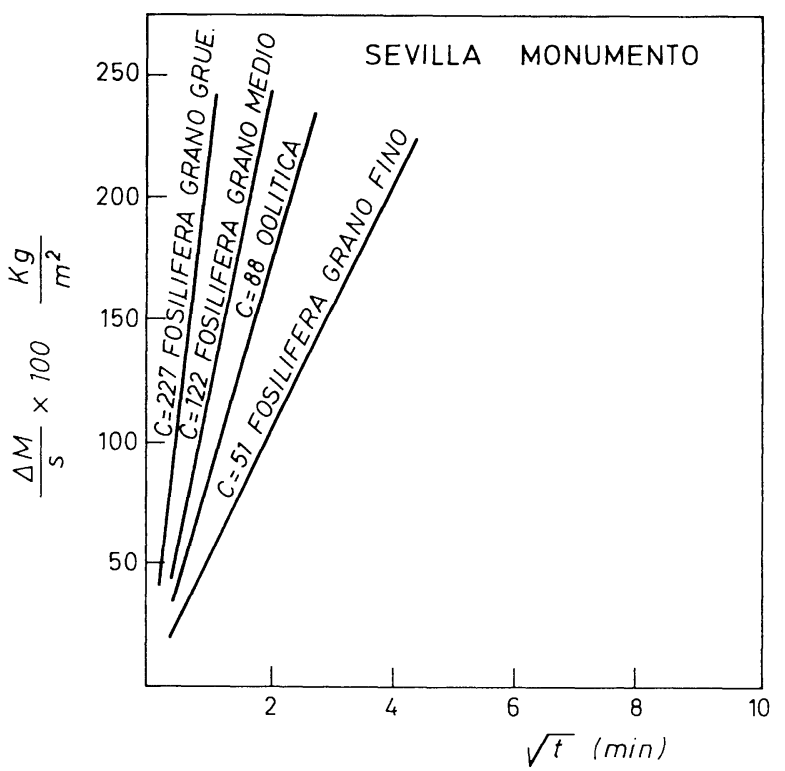

Fig. 10.-Masa de agua absorbida por capilaridad en relación al tiempo. $\mathrm{C}=$ coeficiente de capilaridad. Piedras de Sevilla (Catedral).

Fig. 10.-Mass of water absorbed by capillarity, in relation to time. $C=$ coefficient of capillarity. Seville stones (Cathedral).

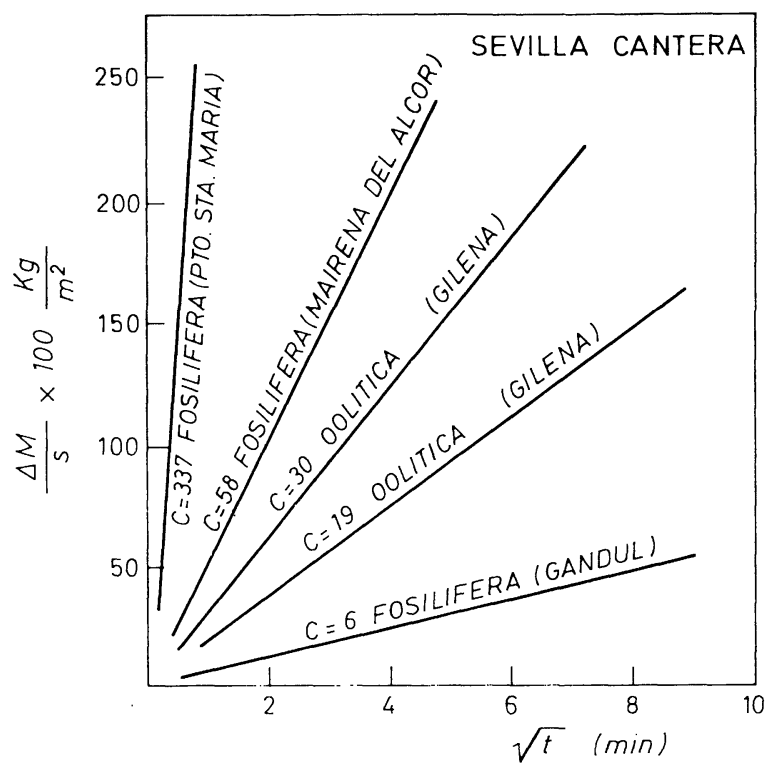

Fig. 11.-Masa de agua absorbida por capilaridad en relación al tiempo. $\mathrm{C}=$ coeficiente de capilaridad. Piedras de Sevilla (Cantera).

Fig. 11.-Mass of water absorbed by capillarity, in relation to time. $C=$ coefficient of capillarity. Seville stones (Quarry).

TABLA IV

Análisis porométrico

\begin{tabular}{|l|c|c|c|c|}
\hline \multicolumn{1}{|c|}{ Tipo de pledra } & $\mathbf{1}$ & $\mathbf{2}$ & $\mathbf{3}$ & $\mathbf{4}$ \\
\hline Catedral: & & & & $9,3-16$ \\
Fosilifera & $14,4-27,2$ & $0-14$ & $73-26,6$ & 9,6 \\
Micrítica & 19 & 0 & 19 & 8,7 \\
Oolítica & 16 & 9,3 & 6,7 & 12,0 \\
\hline Cantera: & 19,4 & & 5,4 & $5,2-6,4$ \\
Fosilifera & $8,8-13,8$ & 0 & $8,8-13,8$ & \\
Oolítica & & & & \\
\hline
\end{tabular}

1 Porosidad abierta $n_{0}(\%)$.

2 Macroporosidad (\%) $(r>7,5 \mu \mathrm{m})$

3 Microporosidad (\%) $(r<7,5 \mu \mathrm{m})$.

4 Porosidad atrapada $n_{p}(\%)$

TABLE IV

Porometric analysis

\begin{tabular}{|l|c|c|c|c|}
\hline \multicolumn{1}{|c|}{ Type of stone } & 1 & 2 & 3 & 4 \\
\hline Cathedral: & & & & $9,3-16$ \\
$\quad$ Fossiliferous & $14,4-27,2$ & $0-14$ & $73-26,6$ & 9,6 \\
Micritic & 19 & 0 & 19 & 8,7 \\
Oolithic & 16 & 9,3 & 6,7 & 12,0 \\
\hline Quarry: & 19,4 & 14,0 & 5,4 & $5,2-6,4$ \\
Fossiliferous & $8,8-13,8$ & 0 & $8,8-13,8$ & \\
Oolithic & & &
\end{tabular}

1 Open porosity $n_{0}(\%)$

2 Macroporosity (\%) $(r>7,5 \mu \mathrm{m})$

3 Microporosity $(\%)(r<7,5 \mu \mathrm{m})$.

4 Trapped porosity $n_{p}(\%)$. 
sistema poroso, obteniéndose las distintas fracciones de porosidad abierta que son posibles determinar mediante dicha técnica, Tabla IV (Esbert y Marcos, 1983; Alonso et al, $1987 \mathrm{~b})$. Debe recordarse que estas determinaciones se realizan para caracterizar la roca matriz; así pues, las cavidades o grandes poros que las piedras puedan presentar, observables a simple vista, no se analizan mediante esta técnica.

En el caso de la piedra oolítica del monumento, la fosilífera de cantera y alguna fosilífera del monumento, la porosidad comunicada es debida tanto a macroporos (radio de acceso superior a 7,5 micras), como a microporos (radio de acceso inferior a 7,5 micras). En las piedras micríticas del monumento y oolíticas de cantera, la porosidad abierta o comunicada se debe exclusivamente a microporos.

En todas ellas, un porcentaje más o menos considerable de esta porosidad comunicada se debe a poros con difícil acceso, como puede comprobarse por los comparativamente altos valores de la porosidad atrapada.

En las Figs. 12 y 13 puede visualizarse, de forma gráfica, el volumen de poros penetrados por el mercurio, asi como los diferentes rangos de distribución de radios de acceso de poro.

\subsection{Propiedades deformacionales}

Para la caracterización del comportamiento mecánico de las piedras de la Catedral de Sevilla y de sus correspondientes de cantera, se han efectuado ensayos de compresión uniaxil siguiendo las recomendaciones de la I.S.R.M. (1981).

En base a los resultados obtenidos en dichos ensayos, se han elaborado las curvas esfuerzo-deformación longitudinal, que permiten calcular los módulos de Young tangente (Et) y secante (Es) (Tabla V). No se han podido estudiar las características deformacionales de la variedad micrítica, por no disponer de un número de muestras representativo para la realización de tales ensayos. En la citada Tabla, como en las siguientes, se indica el rango de variación cuando la dispersión de resultados es grande; y el valor medio cuando los valores son próximos entre sí.

En la Fig. 14 se representa una curva plastoelasto-plástica, típica de la caliza oolítica de cantera. En ella se muestra la evolución de la deformación longitudinal frente al esfuerzo, así como los puntos que se han considerado para porosimmetry, obtaining the different fractions of the open (communicated) porosity that are possible to determine through this technique, Table IV (Esbert and Marcos, 1983; Alonso et al., 1987b). It must be reminded that these measurements are carried out to characterize the intact rock. Thus, the cavities or large pores that the stone could present, observable at first sight, are not analyzed through this technique.

Communicated porosity is due both to macropores (pore throat radius higher than 7,5 microns) and to micropores (pore throat radius lower than 7,5 microns), for the oolithic stone of the monument, the fossiliferous from quarry, and some fossiliferous samples of the monument. In the micritic stone of the monument and oolithic from quarry, the open porosity is exclusively due to micropores.

In all types, a more or less considerable percentage of this communicated porosity is due to pores with a difficult access, as can be proved by the comparatively high values of the trapped porosity.

In Figs. 12 and 13 it is possible to visualize the volume of pores penetrated by mercury, as well as the different ranges of pore size distributions.

\subsection{Deformational properties}

For characterizing the mechanical behaviour of the stones of the Seville Cathedral and their correspondents from quarries, uniaxial compression tests have been carried out following the suggested methods of the I.S.R.M. (1981).

On the basis of the obtained results, stressstrain (longitudinal) curves, permitting to calculate the tangent (Et) and secant (Es) Young modulii, have been plotted in Table V. The deformational characteristics of the micritic limestone were not included here, because a representative number of samples were nor available. In the above mentioned Table, as in the following ones, the range of variation is indicated when the dispersion of results is very great; and only the mean value is exposed when the values are close one to other.

In Fig. 14 is shown a plasto-elasto-plastic curve typical of the oolithic limestone from quarry. In this curve is shown the evolution of the longitudinal deformation with respect the stress applied, as well as the points considered 


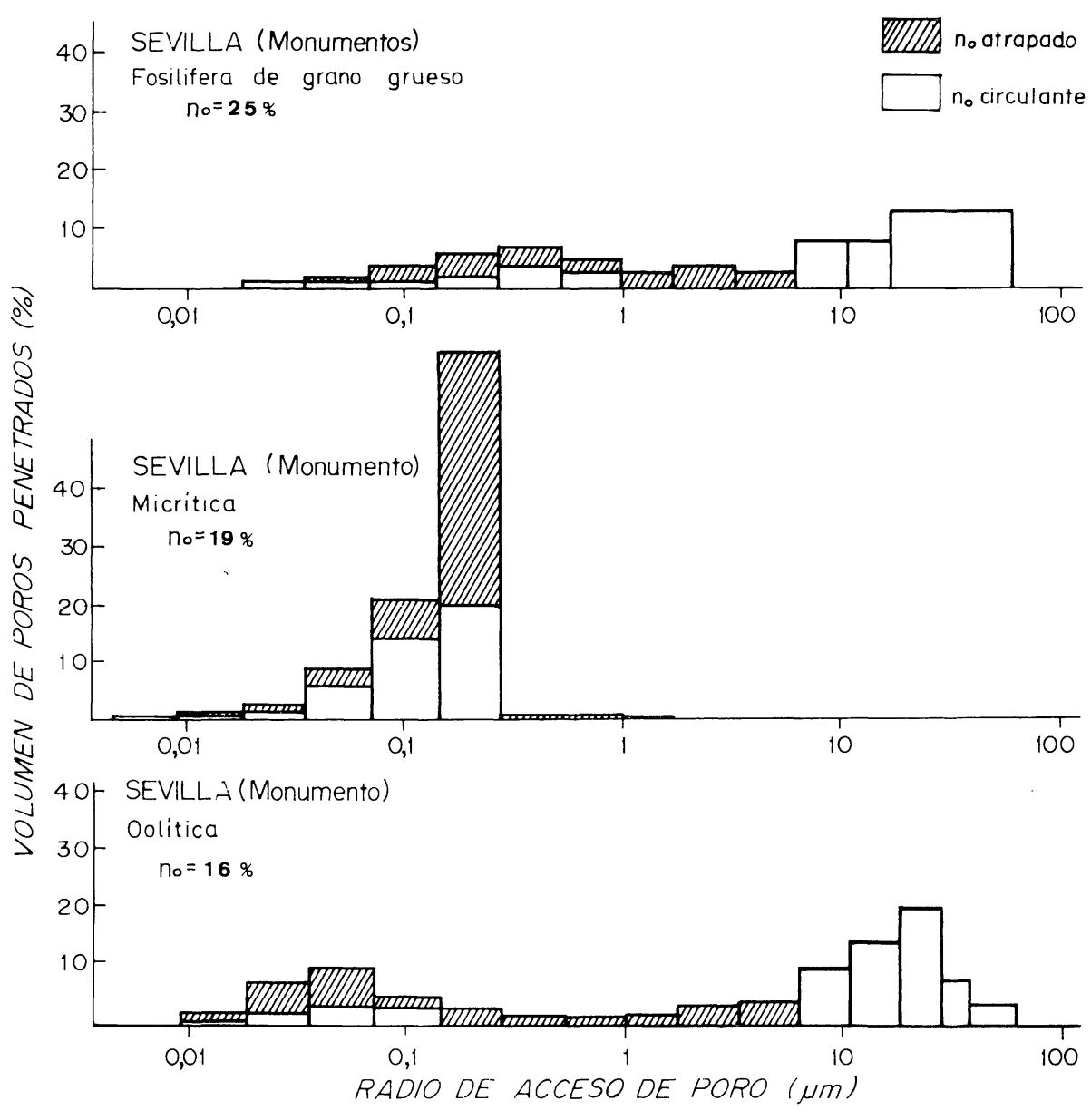

Fig. 12.-Histogramas de distribución del volumen de poros penetrados por $\mathrm{Hg}$, en relación al radio de acceso de los mismos. Piedras de Sevilla (Catedral).

Fig. 12.-Histograms of the volume of pores penetrated by $\mathrm{Hg}$, in relation to the pore throat radii. Seville stones (Cathedral).

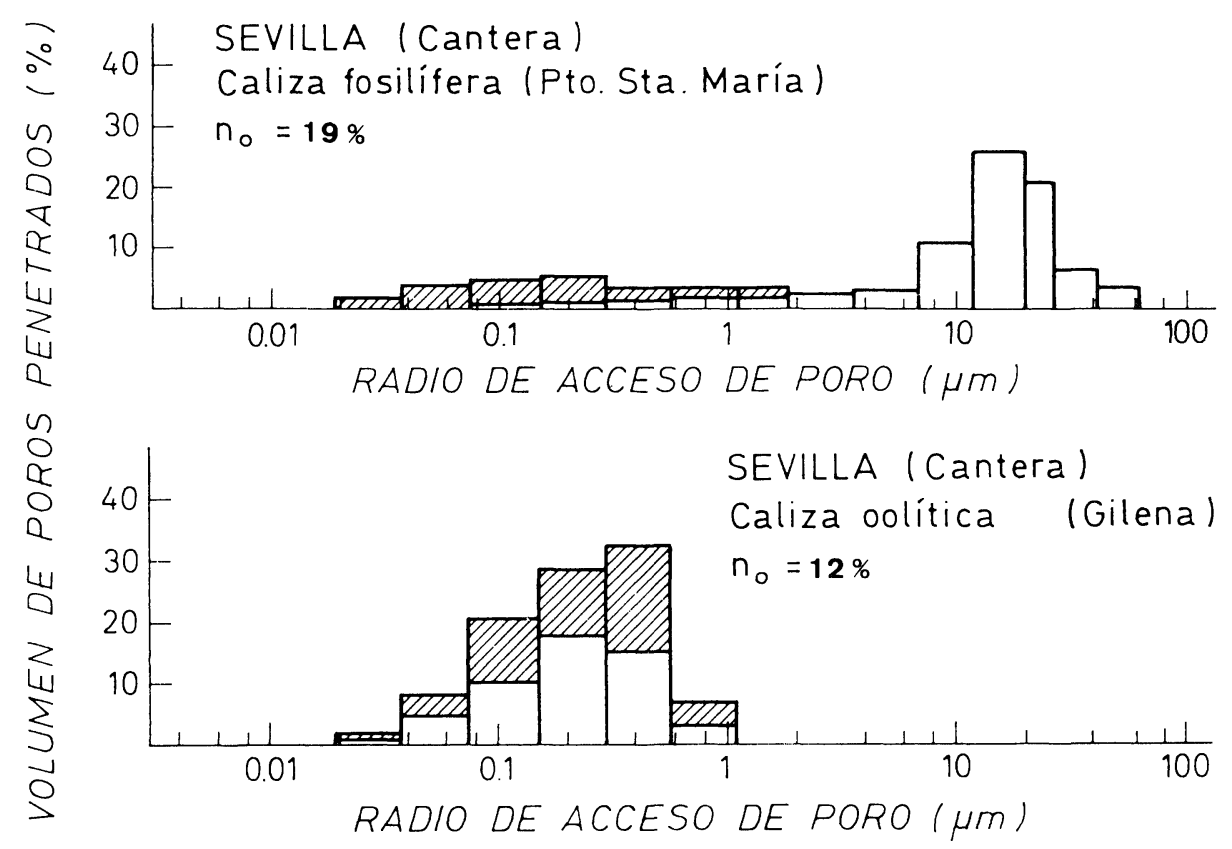

Fig. 13.- Histogramas de distribución del volumen de poros penetrados por $\mathrm{Hg}$, en relación al radio de acceso de los mismos. Piedras de Sevilla (Cantera).

Fig. 13.-Histograms of the volume of pores penetrated by $\mathrm{Hg}$, in relation to the pore throat radii. Seville stones (Quarry). 
el cálculo de los módulos anteriormente mencionados.

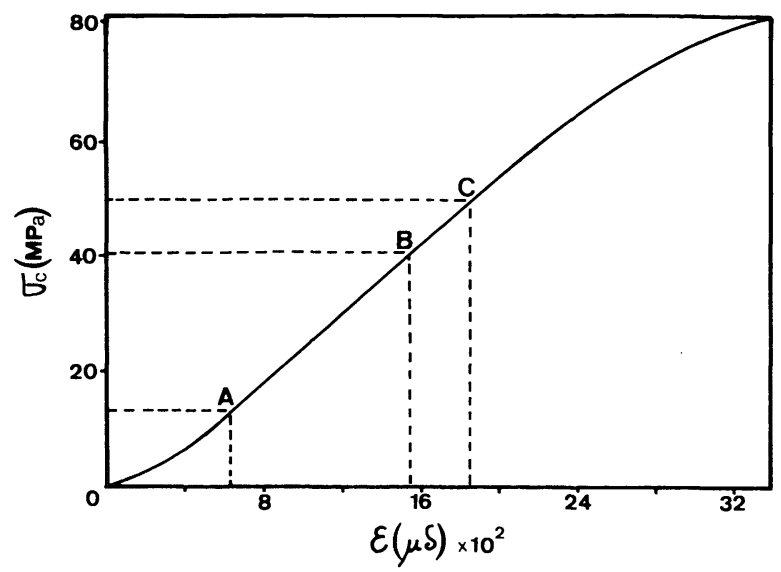

Fig. 14.-Curva típica de esfuerzo-deformación longitudinal correspondiente a la caliza oolítica de cantera. El punto $\mathrm{B}$ correspnde al $50 \%$ de la resistencia final a la rotura. El tramo AC es la parte del intervalo elástico en que se calculó Et.

Fig. 14.-Typical stress-strain (longitudinal) curve corresponding to the oolithic limestone from quarry. Point $B$ corresponds to $50 \%$ of the final failure. The step $A C$ is the part of the elastic interval where the Et was calculated.

TABLA V

Características deformacionales estáticas

\begin{tabular}{|l|c|c|c|c|}
\hline \multicolumn{1}{|c|}{ Tipo de piedra } & $\begin{array}{c}\text { Rc } \\
(\mathrm{MPa})\end{array}$ & $\begin{array}{c}\text { Et } \\
\left(\mathrm{MPa} \times 10^{3}\right)\end{array}$ & $\begin{array}{c}\text { Es } \\
\left(\mathrm{MPa} \times 10^{3}\right)\end{array}$ & $\begin{array}{c}\text { U.M.M. } \\
(\% \mathrm{Rc})\end{array}$ \\
\hline Catedral: & & & - & - \\
$\quad$ Fosilifera & $3-12$ & - & 6,5 & - \\
Oolítica & 22,5 & 6,5 & - & 85 \\
\hline Cantera: & & - & $1-9$ & $60-80$ \\
Fosilifera & $3-30$ & $1,5-5$ & \\
Oolítica & $41-102$ & & & \\
\hline
\end{tabular}

Rc $\quad=$ Resistencia a la compresión uniaxil.

$\begin{array}{ll}\text { Et } & =\text { Módulo de Young tangente. } \\ \text { Es } & =\text { Módulo de Young secante. }\end{array}$

U.M.M. = Umbral de microfisuración mecánica.

TABLE V

Static deformational characteristics

\begin{tabular}{|l|c|c|c|}
\hline \multicolumn{1}{|c|}{ Type of stone } & $\begin{array}{c}\text { Rc } \\
(\mathrm{MPa})\end{array}$ & $\begin{array}{c}\text { Et } \\
\left(\mathrm{MPa} \times 10^{3}\right)\end{array}$ & $\begin{array}{c}\text { Es } \\
\left(\mathrm{MPa} \times 10^{3}\right)\end{array}$ \\
\hline $\begin{array}{l}\text { Cathedral: } \\
\text { Fossiliferous }\end{array}$ & $3-12$ & - & - \\
Oolithic & 22,5 & 6,5 & 6,5 \\
\hline Quarry: & & - & - \\
Fossiliferous & $3-30$ & $1,5-5$ & $1-9$ \\
Oolithic & $41-102$ & $60-80$ \\
\hline
\end{tabular}

$\begin{array}{ll}\mathrm{Rc} & =\text { Uniaxial compressive strength } \\ \mathrm{Et} & =\text { Young modulus (tangent). }\end{array}$

Et = Young modulus (tangent)

U.M.M. = Mechanical microfissuration threshold. 
La variación en el tramo elástico intermedio (AC) es la causa de las diferencias en los módulos de elasticidad, presentando valores considerados usuales para este tipo de materiales sedimentarios. La dispersión de resultados en la variedad fosilífera se debe básicamente a variaciones en la porosidad, el tamaño de grano y el contenido en cuarzo; y en el caso de la oolítica a diferencias en el porcentaje y dimensiones de los oolitos.

Asimismo, se ha determinado el "umbral de microfisuración mecánica" (U.M.M.) a partir del estudio de las morfologías de las curvas de emisión acústica/actividad microsísmica (E.A./A.M.) registrada durante los ciclos de carga, y en base a las interpretaciones que de este tipo de registro han realizado diversos autores (e.g. Ohnaka y Mogi, 1982; Suárez del Río et al., 1984). Los U.M.M. determinados tienden a situarse a porcentajes de la resistencia relativamente elevados para este tipo de materiales rocosos.
The variation in the elastic intermediate step $(A C)$ is the cause of the differences in the elasticity modulii, preseting values considered as usual for this type of sedimentary materials. The dispersion of results in the fossiliferous variety is basically due to variations in porosity, grain size and quartz content; and in the case of the oolithic stone to differences in the percentages and dimensions of the ooliths.

The "mechanical microfissurstion threshold" (M.M.T.) has also been determined from the study of the curves of acoustic emission/microseismic activity (A.E./M.A.) monitored during the cycles of loading, and on the basis of the interpretations of those phenomena by different authors (e.g. Ohnnaka and Mogi, 1982; Suárez del Río et al., 1984). The determined M.M.T. tends to situate at percentages of strength relatively high for these types of rock materials.

TABLA VI

Características deformacionales dinámicas

\begin{tabular}{|c|c|c|c|c|}
\hline Tipo de piedra & $\begin{array}{c}\mathbf{V}_{\mathrm{L}} \\
\mathrm{m} / \mathrm{seg}\end{array}$ & $\begin{array}{c}\mathbf{V}_{\mathbf{T}} \\
\mathrm{m} / \mathrm{seg}\end{array}$ & $\mathrm{MPa} \times 10^{4}$ & $v$ \\
\hline \multicolumn{5}{|l|}{ Catedral: } \\
\hline Fosilífera & $2.400-3.000$ & $1.370-1.545$ & $0,8-1,2$ & $0,25-0,3$ \\
\hline Oolítica & 4.375 & 1.200 & 0,9 & 0,45 \\
\hline \multicolumn{5}{|l|}{ Cantera: } \\
\hline Fosilifera & $3.035-3.913$ & $1.420-1.967$ & $1,1-2,35$ & $0,33-0,36$ \\
\hline Oolítica & $4.700-5.420$ & $2.085-2.700$ & $2,75-4,7$ & $0,35-0,45$ \\
\hline
\end{tabular}

$V_{L}=$ Velocidad de ondas longitudinales.

$V_{T}=$ Velocidad de ondas transversales.

$E$ = Módulo de Young dinámico.

$v$ = Módulo de Poisson dinámico.

TABLE VI

Dynamic deformational characteristics

\begin{tabular}{|l|c|c|c|c|}
\hline \multicolumn{1}{|c|}{ Type of stone } & $\begin{array}{c}\mathbf{V}_{\mathrm{L}} \\
\mathrm{m} / \mathrm{seg}\end{array}$ & $\begin{array}{c}\mathbf{V}_{\mathbf{T}} \\
\mathrm{m} / \mathrm{seg}\end{array}$ & $\mathrm{MPa} \times 10^{4}$ & $v$ \\
\hline $\begin{array}{l}\text { Cathedral: } \\
\text { Fossiliferous }\end{array}$ & $2.400-3.000$ & $1.370-1.545$ & $0,8-1,2$ & $0,25-0,3$ \\
Oolithic & 4.375 & 1.200 & 0,9 & 0,45 \\
\hline Quarry: & & & & $0,33-0,36$ \\
Fossiliferous & $3.035-3.913$ & $1.420-1.967$ & $1,1-2,35$ & $0,35-0,45$ \\
Oolithic & $4.700-5.420$ & $2.085-2.700$ & $2,75-4,7$ & \\
\hline
\end{tabular}

$V_{L}=$ Longitudinal wave velocity

$V_{T}=$ Transversal wave velocity.

$\mathrm{E}^{\top}=$ Dynamic Young modulus.

$v=$ Dynamic Poisson ratio. 
Las constantes elásticas dinámicas se han calculado aplicando las fórmulas sugeridas por la A.S.T.M. (D. 2845). En la Tabla VI se relacionan los resultados obtenidos.

Los valores, tanto de $V_{L}$ y $V_{T}$, como del módulo de Young y de la relación de Poisson dinámicos, abarcan un amplio espectro para los materiales ensayados. Esta relativamente alta dispersión de resultados es consustancial con la naturaleza petrográfica variable de estos materiales.

Por lo que respecta a la comparación entre los materiales pétreos de monumiento y de cantera, se observa generalmente en los primeros un decrecimiento relativo de sus propiedades geomecánicas (resistencia a la compresión, constantes elásticas dinámicas y estáticas).

\section{ALTERABILIDAD}

Con objeto de evaluar la alterabilidad de los materiales pétreos estudiados, se llevaron a cabo los siguientes ensayos de envejecimiento artificial acelerado: Humedadsequedad, hielo-deshielo y cristalización de sales.

En los ensayos de humedad-sequedad y de heladicidad se completaron 30 ciclos: de absorción (imbibición) y desorción (desecación) de agua, en el primer caso; y de congelación $\left(\mathrm{a}-14^{\circ} \mathrm{C}\right)$ y descongelación (a temperatura ambiente), en el segundo. Para el ensayo de cristalización de sales se utilizó una solución acuosa de sulfato sódico decahidratado, al $14 \%$, siendo el número de ciclos efectuados de 10. En todos los casos se emplearon probetas cúbicas de $4 \mathrm{~cm}$ de arista. El número de probetas ensayadas, para cada variedad rocosa, fue de 4 . Una descripción detallada de los procedimientos seguidos en dichos ensayos puede verse, por ejemplo, en Esbert y Ordaz (1985) y Alonso et al. (1987c).

La valoración de los ensayos se hizo a partir de la cuantificación de las pérdidas de material producidas en las probetas, durante y después de los ensayos, expresándose en forma de porcentaje con respecto a su peso original en seco; así como de la observación cualitativa de los daños superficiales generados en las mismas.

Los materiales ensayados corresponden al monumento (caliza fosilífera) y a canteras. De estas últimas se ensayaron variedades de calizas fosilíferas procedentes de Gandul, Mairena del Alcor y Puerto de Santa María (Cerro de San Cristóbal), y la oolítica de Gilena.
The dynamic elastic constants were calculated applying the formulae suggested by the A.S.T.M., 1976). In Table VI these values are exposed.

The values of $V_{L}$ and $V_{T}$, as well as the two dynamic modulii (Young and Poisson), displays a broad range for the studied materials. This relatively high dispersion of results is inherent to the variable petrographical nature of these stones.

As for as the comparison between the monument and quarry stones is concerned, in the former it is generally observed a relative decrease of their geomechanical properties (compressive strength, dynamic and static elastic constants).

\section{WEATHERABILITY}

With the aim of evaluating the weatherability of the stones studied, the following artificial ageing tests were carried out: wetting-drying, freezing-thawing and salt crystallization.

30 cycles of water absorption (imbibition) and desorption (dessication) were performed in the wetting-dryng test; and the same number for the freezing (up to $-14^{\circ} \mathrm{C}$ ) and thawing (at room temperature) cycles. As for the salt crystallization test is concerned, 10 cycles were performed, the aqueous solution used being decahydrated sodic sulphate (at $14 \%$ ). In all the cases $4 \mathrm{~cm}$ cubic specimens were used. The number of specimens tested for each rock variety was 4 . A detailed description of the procedures for these tests can be found, for instance, in Esbert and Ordaz (1985) and Alonso et al. (1987c).

The test assessment was made quantifying the material losses produced in the specimens during and after the cycles, and expressed as a percentage of their initial dry weights; as well as from qualitative observations of the surficial damages generated in the specimens.

The materials tested are from the monument (fossiliferous limestone) and from quarries. Of the latter, some varieties of fossiliferous limestone from Gandul, Mairena del Alcor and Puerto de Santa María (Cerro de San Cristóbal), and the oolithic one from Gilena 
No se pudieron realizar ensayos de las variedades micrítica y oolítica del monumento, por no disponer de un mínimo de muestras representativo. Los resultados se muestran en la Tabla VII. were tested. The micritic and oolithic varieties from the monument could not be tested, because a minimun of representative samples were not available. The results are shown in Table VII.

TABLA VII

Pérdidas de masa (\%) en los ensayos de alterabilidad

\begin{tabular}{|l|c|c|c|}
\hline \multicolumn{1}{|c|}{ Tipo de piedra } & Humedad-sequedad & Hielo-deshielo & Cristalización de sales \\
\hline $\begin{array}{l}\text { Catedral: } \\
\text { Fosilifera }\end{array}$ & $0,05-0,3$ & & \\
\hline Cantera: & & $0,2-0,5$ & $6,5-10,2$ \\
Fosilífera & $0,06-0,2$ & $0,06-0,3$ & $0,3-2,2$ \\
Oolítica & 0,0 & $0,0-0,04$ & $0,5-4,5$ \\
\hline
\end{tabular}

TABLE VII

Mass losses (\%) in the weatherability tests

\begin{tabular}{|l|c|c|c|}
\hline \multicolumn{1}{|c|}{ Type of stone } & Wetting-drying & Freezing-thawing & Salt Crystallization \\
\hline $\begin{array}{l}\text { Cathedral: } \\
\text { Fossiliferous }\end{array}$ & $0,05-0,3$ & & \\
\hline Quarry: & $0,06-0,2$ & $0,2-0,5$ & $6,5-10,2$ \\
Fossiliferous & 0,0 & $0,06-0,3$ & $0,3-2,2$ \\
Oolithic & $0,0-0,04$ & $0,5-4,5$ \\
\hline
\end{tabular}

A la vista de los valores obtenidos, puede decirse que, en conjunto, las piedras del monumento se comportan peor que sus homólogas de canteras, en todos los ensayos realizados. En el ensayo de cristalización de sales -el más agresivo de los tres- las pérdidas de masa experimentadas por las muestras de caliza fosilífera extraídas de la catedral son aproximadamente el cuádruple de las producidas en las variedades de cantera, lo que vendría a indicar un grado de alteración inicial superior en la piedra del monumento.

En los ensayos de humedad-sequedad y heladicidad las probetas, tanto de monumento como de cantera, sufrieron pérdidas mínimas, que en el caso de la variedad oolítica son prácticamente nulas. La durabilidad de los materiales estudiados, frente a las acciones del agua líquida y el hielo, puede considerarse pues, en principio, como alta.

Desde el punto de vista cualitativo, de modificaciones superficiales, las probetas del monumento presentan, al término de los ensayos, señales de desagregación grano a
In sight of the values obtained, it can be said that generally, the monument stones present a worse behaviour than the homologous ones from the quarries, in all the tests performed. In the salt crystallization test - the most aggressive of the three- the material losses exhibited by the samples of fossiliferous limestones extracted from the cathedral are approximately four times greater than the ones produced in the quarry varieties, hence indicating a higher initial weathering degree in the stones of the monument.

In the wetting-drying and freezing-thawing cycles the specimens from the monument and quarries underwent minimum losses, that in the case of the oolithic limestone are practically null. The durability of the materials studied, with respect to the effects of the liquid water and ice, can be essentially considered as high.

From the qualitative point of view of the surficial changes, the specimens from the monument present, at the end of the tests, signals of a grain-by-grain disaggregation, this 
grano, siendo esta desagregación especialmente evidente después del ensayo de cristalización de sales (Fig. 15). Las variedades de cantera apenas se ven afectadas externamente por los ciclos de humedad-sequedad y hielo-deshielo; tan sólo en las probetas de piedra oolítica sometidas a cristalización de sales se observan pequeñas fracturas en las caras y saltaciones en los bordes, con esporádicas desconchaduras favorecidas por la presencia de alguna fisura preexistente. En las variedades fosilíferas los daños superficiales son generalmente menores, manifestándose particularmente en forma de picadura. disaggregation being especially evident after the salt crystallization test (Fig. 15). The varieties from the quarries are scarcely affected externally by the wetting-drying and freezing-thawing cycles; only the specimens of oolithic stone subdued to salt crystallization present small fractures and sporadical scaling off, favoured by the presence of preexisting fissures. In the fossiliferous ones, the surficial damages are generally lesser, and become especially apparent under the form of pitting.

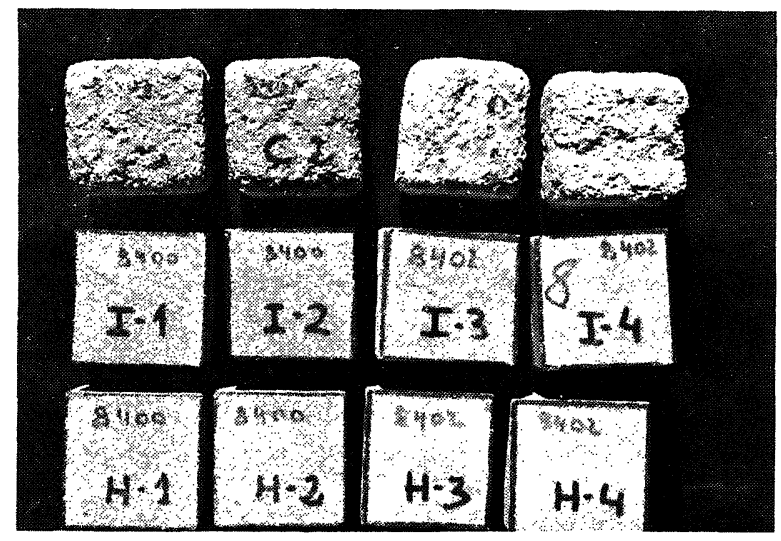

Fig. 15.-Probetas de caliza fosilífera después de los ensayos de alterabilidad. Parte superior: cristalización de sales; centro: hielo-deshielo; inferior: humedad-sequedad.

\section{CONCLUSIONES}

De acuerdo con las observaciones y análisis efectuados, se pueden extraer las siguientes conclusiones generales:

- La variedad de piedra utilizada con mayor profusión en la fábrica de la Catedral de Sevilla ha sido una caliza fosilífera (biocalcarenita). En menor proporción han sido utilizados otros tipos calcáreos: calizas oolítica y micrítica. Se han localizado las formaciones geológicas a las que pertenecen las citadas piedras, así como varias canteras emplazadas en dichas formaciones, excepto para la caliza micrítica, cuya procedencia se desconoce.

- Las características mineralógico-texturales de las variedades fosilifera y oolítica suelen ser variables, tanto en lo que se refiere a los porcentajes relativos de los diferentes componentes minerales, como en el tamaño de grano de los mismos y en la proporción de fase aglomerante. De igual forma se constata una amplia variación en las propiedades físicas, especialmente en la caliza fosilífera.
Fig. 15.-Specimens of fossiliferous limestone after the weatherability tests. Upper part: salt crystallization; Centre: freezing-thawing; Lower part: wetting-drying.

\section{CONCLUSIONS}

According to the observations and analyses realized, the following general conclusions can be stated:

- The stone variety most profusely used in the fabric of the Seville Cathedral has been a fossiliferous limestone (biocalcarenite). In a lesser proportion, other calcareous types have been also used: micritic and oolithic limestones. The geological formations to which these stones pertain have been located, as well as several quarries situated in those formations, except for the micritic one, whose provenience is unknown.

- The mineralogical-textural characteristics of the fossiliferous and oolithic varieties are variable, not only as for the relative percentages of the different mineral components are concerned, but also for the grain sizes and the proportion of the agglomerating phase. Similarly, broad variations of the physical properties, especially for the fossiliferous limestone, have been confirmed. 
- Todas las piedras estudiadas presentan valores altos de porosidad abierta, siendo ésta más elevada en las variedades del monumento que en las correspondientes de cantera. La piedra más porosa es la caliza fosilífera (14\% a $30 \%)$, seguida de la micrítica (alrededor del $18 \%$ ). La variedad oolítica presenta una porosidad comunicada menor ( $8 \%$ a $17 \%$ ). Del análisis porométrico se deduce que la porosidad comunicada de las piedras estudiadas puede atribuirse tanto a macroporos como a microporos, a excepto para la piedra micrítica que es esencialmente microporosa.

- En relación con la absorción de agua por parte de las piedras, puede decirse que las que más agua absorben son las del monumento. En la cinética de absorción todas ellas muestran un comportamiento similar: Absorben rápidamente el agua en unos pocos minutos, estabilizándose a continuación. En cuanto a la succión capilar, el comportamiento es muy dispar, dentro incluso de una misma variedad. En la caliza fosilífera del monumento, por ejemplo, varía de valores bajos $\left(51 \mathrm{Kg} / \mathrm{m} \cdot \mathrm{h}^{1 / 2}\right)$ a muy altos $\left(227 \mathrm{Kg} / \mathrm{m} \cdot \mathrm{h}^{1 / 2}\right)$.

- Desde el punto de vista geomecánico, los materiales pétreos del monumento muestran un debilitamiento relativo con respecto a sus correspondientes de cantera. La porosidad, el tamaño de grano y el contenido en cuarzo (en el caso de la piedra fosilífera), son tres de los factores petrográficos que más influyen en el comportamiento mecánico y deformacional de estos materiales, dando lugar a una gran variabilidad de resultados. El umbral de microfisuración mecánico se sitúa a porcentajes de la resistencia a la compresión (60-85\%) relativamente altos para este tipo de rocas.

- En todos los ensayos de alterabilidad efectuados, las piedras del monumento se comportan peor que sus correspondientes de cantera. Los ensayos de humedadsequedad y de hielo-deshielo apenas ocasionan daños superficiales, con pérdidas de masa mínimas. El ensayo de cristalización de sales provoca pérdidas de material, por desagregación granular, que se sitúan entre el 6 y el $10 \%$ para la piedra fosilífera del monumento, siendo menores (0,3-4,5\%) en las muestras fosilíferas y oolíticas de cantera.

\section{AGRADECIMIENTOS}

A la Fundación Ramón Areces, por la ayuda económica para la realización de este estudio.
- All the studied stones present high values of open porosity, this porosity being higher in the monument stones than in their corresponding ones from the quarries. The most porous one is the fossiliferous limestone (14\% to $30 \%$ ), followed by the micritic one (around $18 \%$ ). The oolithic variety presents a lesser communicated porosity (8 \% to $17 \%$ ). From the porometric analysis it can be deduced that the communicated porosity is due to both macropores and micropores, except for the micritic stone, that is basically microporous.

- With respect to the water absorption by the stones, it can be said that the most absorbent ones are those from the monument. Kynetically, all varieties show a similar behaviour: Quick absorption during the first minutes, and after a stabilization. As for as the capillary suction is concerned, the behaviour is very dissimilar, even within a same variety. In the fossiliferous stones from the monument, for instance, this property varies from low values $\left(51 \mathrm{Kg} / \mathrm{m} . \mathrm{h}^{1 / 2}\right)$ to very high $\left(227 \mathrm{Kg} / \mathrm{m} \cdot \mathrm{h}^{1 / 2}\right)$.

- From the geomechanical point of view, the stones of the monument show a relative weakening with respect to their corresponding ones from the quarries. Porosity, grain size and quartz content (in the case of the fossiliferous stone), are three of the petrographical factors most influencing the mechanical and deformational behaviour of these materials, thus favouring a great range of results. The mechanical microfissuration threshold is detected at percentages of compressive strength (60-85\%) relatively high for this type of rocks.

- In all the weatherability tests carried out, the monument stones behave worse than their correspondent from the quarries. The wetting-drying and freezing-thawing tests barely induce superficial damages, with minimun mass losses. The salt crystallization test causes material losses, by granular disaggregation, between $6 \%$ and $10 \%$, for the fossiliferous limestone, these losses being lesser (0,3\%-4,5\%) in the fossiliferous and oolithic quarry samples.

\section{ACNOWLEDGMENTS}

To the Ramón Areces Foundation, for the economic support for the realization of this study. 


\section{BIBLIOGRAFIA}

ALONSO, F. J.; R. M. ESBERT y J. ORDAZ (1987a): Comportamiento hídrico de calizas y dolomías. Bol. Geológico y Minero, 98, pp. 555-576.

ALONSO, F. J.; R. M. ESBERT y J. ORDAZ (1987b): Caracterización del sistema poroso de calizas y dolomías. Bol. Geológico y Minero, 98, pp. 226-237.

ALONSO, F. J.; J. ORDAZ; L. VALDEON y R. M. ESBERT (1987c): Revisión crítica del ensayo de cristalización de sales. Materiales de Construcción, 37 (206), pp. 53-60.

A.S.T.M. (1976): Standard method for laboratory determination of pulse velocities and ultrasonic elastic constants of rock. 1976 Annual Book of A.S.T.M. Standards, Part 19, Norm D 2845-69, pp. 356-363.

C.N.R.-I.C.R. (1981): Assorbimento d'acqua per inmersione totale. Capacitá di imbibizioni. Doc. Normal: 11/82, Roma, 5 p.

C.N.R.-I.C.R. (1981): Assorbimento d'acqua per capilaritá. Coefficiente di assorbimento capillare. Doc. Normal: 11/82, Roma, $6 \mathrm{p}$.

DUNHAM, R. J. (1962): Classification of carbonate rocks according to depositional texture. In: Classification of Carbonate Rocks, W.E. Ham (Ed.), Symp. Am. Ass. Pet. Geol., pp. 108-121.

ESBERT, R. M. y R. MARCOS (1983): Las piedras de la Catedral de Oviedo y su deterioración. Publ. Colegio Oficial de Aparejadores y Arquitectos Técnicos de Asturias, Oviedo, 144 p.

ESBERT, R. M. y J. ORDAZ (1985): Alterabilidad de la piedra monumental de Laspra (Asturias). Trabajos de Geología, Univ. de Oviedo, 15, pp. 325-331.

FALCON, T. (1985): El edificio gótico. Los materiales constructivos. En: "La Catedral de Sevilla", Ediciones Guadalquivir, Sevilla, pp. 137-139.

I.S.R.M. (1981): Rock characterization testing and monitoring. ISRM Suggested Methods. (E.T. Brown, Ed.) Pergamon Press, $211 \mathrm{p}$.

MARTIN, A.; M. ALCALDE; J. VALE y R. VILLEGAS (1987): The Cathedral of Seville; present state of conservation. Pore structure and Construction Materials Properties (J. C. Maso, ed.), Vol. 1, Chapman and Hall, London-New York, pp. 1.1701.173.

OHNAKA, M. y K. MOGI (1982): Frequency characteristics of A. E. in rock under uniaxial compression and its relation to the fracturing process to failure. Journal Geophysics Research, 87, B-5, pp. 3.873-3.884.

SUAREZ DEL RIO, L. M.; J. ORDAZ; V. G. RUIZ DE ARGANDOÑA, y L. CALLEJA (1984): Determinación experimental del umbral de microfisuración en rocas sometidas a esfuerzos compresivos. I Cong. Esp. de Geología, Segovia, 3, pp. 497-508.

\section{publicación del IETcc/CSIC}

\section{ACUEDUCTOS ROMANOS EN ESPAÑA \\ Carlos Fernández Casado}

Prof. Dr. Ing. de Caminos, Canales y Puertos

Esta publicación se compone de una serie de articulos, publicados en la Revista "Informes de la Construcción", en los cuales se hace un análisis de los acueductos romanos que existen en España y el balance de las condiciones de conservación en que se encuentra cada uno de ellos, incluyendo referencias históricas y literarias. Se ha ilustrado con la reproducción de la valiosa documentación gráfica que posee el prestigioso autor.

Un volumen encuadernado en couché, a dos colores, de $21 \times 27$ centimetros, compuesto de 238 páginas, numerosos grabados, dibujos, fotos en blanco y negro y figuras de linea.

Precio: España, 900 ptas., 13 \$ USA.

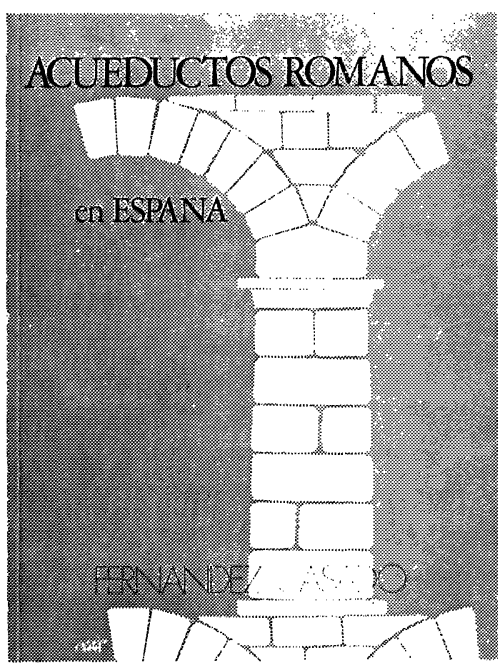

